Then, using the matrix, the cell within which the patient falls can be very easily identified in an objective fashion. If the patient falls within cells $4 a$ and $4 b$, the

special articles decision to use the Act is well established. In fact, as the patient is lacking competence, any decisions not to apply the Act should be carefully considered. However, if the patient is found to fall in cells $2 a$ or $2 b$ as being competent, the Richardson Committee (Department of Health, 1999a) suggests setting a higher standard of risk required before compulsory powers are used, so that patient autonomy is protected.

Avoidance of the use of compulsory treatment where possible is in the spirit of the Mental Health Act, even where lack of competence exists. The function of the matrix is not to prescribe its use, but rather to allow the consideration of appropriateness in a more formal framework. Breaking down the global decision into its component factors and making the steps in consideration of compulsory treatment more explicit, may be helpful in situations where there are multiple factors rendering the decision difficult.

\section{Conclusion}

The issues of competence and the use of compulsory treatment can be very difficult, with individual clinical cases presenting great challenges to clinicians. We were involved in one such difficult case, which led to the development of this matrix.

It is true that in real life these three factors in the matrix are interrelated and each affects the other, as previously discussed. It is also true that clinical decisions must be made on the basis of balancing further factors of urgency, level of risk and the seriousness of the intervention proposed. This matrix is not prescriptive about the course of action that should follow, nor of the scope of definition of the terms mental disorder, risk and competence. Instead, its role is more to aid separate consideration of the different dimensions involved in order to indicate the relevance of compulsory treatment. We would suggest that the use of a simple matrix in difficult cases may aid good practice in decision-making.

\section{References}

BRITISH MEDICAL ASSOCIATION (1995) Assessment of Mental Capacity: Guidance for Doctors and Lawyers. London: BMA.

DEPARTMENT OF HEALTH (1999a) Review of the Mental Health Act 1983 . Draft Outline Proposals by Scoping Study Committee. London: Stationery Office.

- (1999b) Reform of the Mental Health Act 1983: Proposals for

Consultation. Presented to Parliamen by the Secretary of State for Health by

Command of Her Majesty. Cm 4480. London: Stationery Office.

—(2000) Reforming the Mental Health Act. Part 1. The New Legal Framework. Presented to Parliament by the Secretary of State for Health and the Home Secretary by Command of Her Majesty. Cm 5016-I. London: Department of Health.

GRISSO,T. \& APPELBAUM, P. S. (1998) Assessing Competence to Consent to Treatment: A Guide for Physicians and other Health Professionals. Oxford: Oxford University Press.

Lv. Bournewood Community and Mental Health NHS Trust (1997) TLR 8/12/97. ReC (Adult: Refusal of Medical Treatment) (1994) 1 All ER 819. ReL (By His Next Friend GE) (1998) TLR 25/6/98

*JacintaTan Specialist Registrar, Child \& Adolescent Psychiatry, The Park Hospital for Children, Old Road, Headington, Oxford OX5 7LO

Martin Elphick Consultant Psychiatrist, The Elms Clinic, Oxford

\title{
Mentoring for newly appointed consultant psychiatrists
}

The south-west Mentoring Scheme has developed in the context of a general and increasing concern for the health and morale of senior doctors (British Medical Association (BMA), 2000). Their problems are now well described (Allen, 1999; Ghodse et al, 2000), but there is little evidence of effective intervention. The aspirations of the National Service Framework and the NHS Plan will come to nothing if there are not sufficient trained and experienced staff to implement them, and senior staff are increasingly looking forward to early retirement rather than the continued satisfactions of working within the NHS. Recruitment and retention of consultant psychiatrists is the most problematic of all medical specialities, with $14 \%$ of posts empty or occupied by locums (Sainsbury Centre for Mental Health, 2000). There is a clear need to find ways of preventing work-related ill health, stress and burn-out among practitioners (Roberts, 1997; Department of Health, 1999: p 115), and to sustain their creative and productive engagement in health care. A demotivated profession cannot be expected to deliver an effective service (McBride \& Metcalf, 1995; Appleton et al, 1998) and policy is not a substitute for personnel.

\section{The problems of practitioners}

Every study that has looked at the problems currently facing practitioners produces a similar long and depressing list: understaffing, poor premises, low morale, unacceptable workloads, a feeling of being dispossessed of their professional role and autonomy, violence and the fear of violence, a culture of blame, failure of management and a lack of support from colleagues (Williams et al, 1998; Ghose et al, 2000); although consultant psychiatrists work fewer hours than physicians and surgeons, they report more emotional exhaustion and depression (Deary et al, 1996). 


\section{Erosion of professionalism}

Successive governments have sought to limit the autonomy of professionals (Fish \& Coles, 1998), leading to ambiguity and confusion such that, among other remedies, there may be a need to reclaim a robust and contemporary awareness of what it means to be a professional, and rediscover guiding values (Clever, 1999).

Professionalism has been defined as 'the exercise of discretion, on behalf of another, in a situation of uncertainty' (Minzberg, 1983), and over the past 2 decades the literature has reaffirmed that professionals deal with 'indeterminate' problems - ones that often lack a clear solution and are inherently complex and unpredictable. These require professionals to read the situation, to improvise and be flexible.

\section{Blame and error}

Doctors rarely speak about their mistakes with their colleagues (Christensen et al, 1992) and often see errors as failure of character (Vincent, 1999). The general public is disposed to interpret clinical error as medical negligence. There is a need to reconcile idealistic aspirations, enshrined in protocols and guidelines, with the realistic portrayal of clinical practice based on judgements, for 'clinicians are often placed in an invidious position forced to choose between options that are not ideal

... . even the most eminent can be tested to the utmost of their skill, and occasionally fail.' (Asthal et al, 1998: p. 2). The BMA (2000: p. 9) have noted that 'error in medicine is inevitable and extremely frequent'. Nevertheless, the fear of making mistakes weighs heavily upon practitioners.

\section{Isolation}

Doctors (and other professionals) learn to practise primarily through a process of socialisation - by holding conversations with colleagues within a community of other professionals (Eraut, 1994; Fish \& Coles, 1998; Atkinson \& Claxton, 2000; Davis et al, 1997; Downie \& Macnaughton, 2000), and much learning occurs informally during the constant exchange of stories that constitutes the professional day (Hunter, 1991). However, the progressive dispersal of consultant psychiatrists into multi-disciplinary, locality-based teams, has simultaneously been accompanied by relative isolation from their peers, apart from formal meetings to address specific agendas. Nearly $70 \%$ of consultants attending our study days on mentorship stated that they no longer have time for coffee or lunch with their colleagues owing to work pressures - times when 'continuing professional development' occurred naturally.

Lack of a confidant has been associated with, and enhanced risk of, anxiety and depression in health care staff (Weinberg \& Creed, 2000) and psychiatrists frequently feel isolated within a mental health team, citing their relationships with peers as a source of distress. The early years in post are considered to be the most difficult (Holloway et al, 2000) and where opportunity for support, away from the immediate work setting, may arise by preserving special interests and links with professional networks, it would similarly be met by mentoring (SCOPME, 1999).

\section{Mentoring}

Mentoring has the joint aspiration of promoting occupational health and supporting the development of professional confidence, and has recently been identified as an appropriate practice for 'more senior consultants' (Department of Health, 2000a,b) and suggested as one way of responding to the personal and professional challenges of general psychiatric practice, but little has been published on mentoring for senior doctors, or the evaluation of mentoring programmes (Holloway, 2000).

Mentoring is the offer of a confidential, professional and supportive relationship, by an experienced colleague, able and willing to share his or her knowledge and experience to a protégé or mentee. This is different to the more technical processes around clinical governance, which have largely focused on increasing scrutiny and accountability. Peer supervised personal development plans (PDPs) and the processes leading to revalidation may ultimately turn out to be enabling and supportive, following the suggestion that they occur, 'among a group of physicians who tell their stories, sharing their wisdom and compassion' (Royal College of Psychiatrists, 2001), but there is no evidence to support its widespread introduction. Mentoring, however, offers a confidential context in which even these processes can be anticipated, and used to maximum advantage. Mentorship is therefore significantly different to PDPs, appraisal and approval, but is complementary, and supportive of them.

\section{The south-west scheme}

An awareness of the literature (above) and initial enquiry within the South and West Division of the Royal College of Psychiatrists confirmed that many newly appointed consultant psychiatrists felt isolated and experienced high levels of stress. The majority felt ill-prepared for the transition involved in taking up their consultant post.

During 1999 all established consultants (5 years in post) were contacted and asked to meet and help develop an appropriate support system. Those interested in offering themselves as mentors were asked to attend a training and development course with the steering committee. This was designed as a day of mentorship on mentorship, which facilitated self-appraisal; exploring (with others) the experience of stress in psychiatric practice; and enabled the more hesitant to value their experience and realise that they were good enough. The central aims and purposes of mentoring were clarified in discussion with the prospective mentor group (Box 1). In defining the extent of the commitment, possible pitfalls and common mistakes were discussed - boundaries, confidentiality and in particular that mentors do not aim 


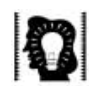

special articles
Box 1. Aims and purposes of the mentoring relationship

- An opportunity for 'mature reflection'

- Confidential advice

- Exploration of professional coping mechanisms

- A sounding board - someone to listen

- Realignment to professional realities, e.g. fallibility and uncertainty

- Setting priorities and managing time

- Induction into the consultant role

- Exploration of organisational culture

- Exploration of guiding values

- Sharing of experience

or offer to be therapists, although they may help to arrange therapy or treatment if that is indicated.

The induction process for mentors was designed to mirror the mentorship relationship and the concluding comments from delegates indicated considerable satisfaction with an opportunity to reflect on their professional lives in the company of experienced colleagues.

\section{Organisation of the scheme}

Newly appointed consultants are contacted by the scheme coordinator (B.M.) with a letter of welcome to their new post, and encouragement to access the scheme. Those responding are offered a choice of four mentors who have produced brief 'pen portraits' to enable mentees to select a colleague with an awareness of their speciality and interests. Mentees are asked to contact their chosen mentor, and to inform the scheme coordinator once arrangements have been agreed. Mentors are offered within a reasonable travelling distance, and outside their own trust, they are asked to support only one colleague, to arrange the first meeting and to encourage regular contact. The mentor's name is then removed from the list of those available. The content of the relationship is confidential but the process is reviewed and monitored by the steering committee.

The south-west group have agreed on a process beginning with an initial meeting when there is an opportunity to discuss the prospect of mentoring without commitment. This may be followed by an initial period of 6 months with the option of opting-out on both sides. A notional 2-year 'contract' is then offered, but it has been regarded as particularly important for the boundaries of the relationship to have a high degree of flexibility and scope for negotiation. The value of a mentoring relationship is based on a complex matching process. There are issues for and against mentoring someone previously known as a trainee, and there needs to be opportunity for an open and frank discussion concerning expectations, which are then kept under regular review. It is a relationship shaped by guidelines rather than rules. Subsequent annual review days with mentors have yielded a description of the mentoring relationship as rich, demanding and complex, and have affirmed that the iterative process of

'returning to the beginning' has proved to be rewarding for both parties.

\section{The future}

The unanticipated difficulty of gaining timely access to information on the whereabouts of newly appointed consultants is being overcome and a year after the scheme's inception there are 14 mentoring pairs; 58 consultants attended the recent review days. The scheme is gaining increasing endorsement from employers and managers at district and regional levels, and is expected to grow within the next year. It is anticipated that the scheme will feature in job descriptions and be incorporated into job plans, serving as an additional attraction to taking a consultant post in the south-west, and thereby offering a positive contribution to the endemic problem of recruitment and retention. Annual induction and review days for mentors will be a means of democratically shaping the development of mentoring in the southwest, and there is an emerging interest in clarifying the needs of mentors, including how best to evaluate the scheme.

\section{Conclusions}

Although consultants form a small portion of the workforce, their morale and functioning have a major effect on health care. An adequate system of support will simultaneously be in the interest of practitioners, patients and their carers, and non-medical colleagues. If appraisal and mentoring of senior doctors is only arranged when there is a perception that the doctor's performance is unacceptable, then it will be met with resistance. An alternative view is that mentorship and other supportive structures are of value to all consultants irrespective of performance, and usefully coexist with formal evaluation.

Mentorship is based on a continued emphasis on 'the person' of the doctor, alongside the acquisition and maintenance of knowledge and skills. It is suggested that the provision of a mentoring relationship for new consultants is only one part of a succession of facilitating relationships, which will optimally start on the first day of medical school, and continuing through the 'seven ages of medical practice', mirroring the progression from undergraduate studies to active retirement.

\section{References}

ALLEN, I. (1999) Stress Amongst Consultants in North Thames. London: NorthThames Department of Postgraduate Medical and Dental Education.

APPLETON, K., HOUSE, A. \& DOWELL, A. (1998) A survey of job satisfaction, sources of stress and psychological symptoms among general practitioners in Leeds. British Journal of General Practice, 48, 1059-1063.
ASTHAL, BARONESS SCOTLAND, KELLEY, H. \& DEVAUX, M. (1998) The Report of the LukeWarm Luke Mental Health Enquiry.Vol. 1. London: Lambeth, Southwark and Lewisham Health Authority.

ATKINSON,T. \& CLAXTON, G. (2000) The Intuitive Practitioner: On the Value of not Always Knowing What One is Doing. Buckingham: The Open University Press. 
BRITISHMEDICAL ASSOCIATION (2000) Work-Related Stress Among Senior Doctors. London: BMA

CHRISTENSEN, J., LEVINSON,W. \& DUNN, P. (1992) The heart of darkness: the impact of perceived mistakes on physicians. Journal of General Internal Medicine, 7, 425-431.

CLEVER, L. (1999) A call to renewal: doctors who feel ground down can renew their spirits and their values. BMJ, 319, 1587-1588.

DAVIS, L. L. LITTLE, M. S. \& THORNTON,W. L. (1997) The art and angst of the mentoring relationship. Academic Psychiatry, 211, 61-71.

DEARY, I., AGIUS, R. \& SADLER, A (1996) Personality and stress in consultant psychiatrists. International Journal of Social Psychiatry, 171, 6-8. DEPARTMENT OF HEALTH (1999) National Service Framework: Mental Health. London: Department of Health.

- (2000a) A Health Service of all the Talents: Developing the NHS Workforce. London: Department of Health.
- (2000b) The NHS Plan. London: Department of Health.

DOWNIE, R. \& MACNAUGHTON, (2000) Professional Judgement: Evidence in Practice. Cambridge: Cambridge University Press.

ERAUT, M. (1994) Developing Professional Knowledge and Competence. Falmer: The Falmer Press.

FISH, D. \& COLES, C. (1998) Developing Professional Judgement in Health Care: Learning Through the Critical Appreciation of Practice. Oxford: Butterworth Heinemann.

GHODSE, H., MANN, S. \& JOHNSON, P. (2000) Doctors and their Health London: Reed Healthcare Publishing.

HOLLOWAY, F., SZMUKLER, G. \& CARSON, J. (2000) Support systems. 1. Introduction. Advances in Psychiatric Treatment, 6, 226-235.

HOLLOWAY, J. (2000) CPD portfolios and personal development plans: why and how? Advances in Psychiatric Treatment, 6, 467-473.
HUNTER, K. M. (1991) Doctors' Stories: The Narrative Structure of Medica Knowledge. Princeton University Press: Princeton.

MCBRIDE, M. \& METCALF, D. (1995) General practitioners' low morale: reasons and solutions. British Journal of General Practice, 45, 227-229.

MINZBERG, H. (1983) Structures in Fives. New York: Prentice Hall.

ROBERTS, G. A. (1997) Prevention of burn-out. Advances in Psychiatric Treatment, 3, 282-289.

ROYAL COLLEE OFPSYCHIATRISTS

(2001) Good Psychiatric Practice: CPD. Council Report CR90. London: Royal College of Psychiatrists.

SAINSBURY CENTRE FOR MENTAL

HEALTH (2000) Finding and Keeping:

Review of Recruitment and Retention in

the Mental Health Workforce. London:

The Sainsbury Centre for Menta

Health.

SCOPME (1999) Doctors and Dentists: The Need for a Process of Review. London: The Standing Committee for Postgraduate Medical and Dental Education.

WIENBERG A \& CREED F (2000) Stress and psychiatric disorder in healthcare professionals and hospital staff. Lancet, 355, 533-537.

WILLIAMS, S., MICHIE, S. \& PATTANI, S (1998) Improving the Health of the NHS Workforce. London: The Nuffield Trust.

VINCENT, C. (1999) Fallibility, uncertainty and the impact of mistakes and litigation. In: Stress in Health Professionals(edsJ. Cozens \& R. Payne). Sussex: Wiley.

Glenn Roberts Consultant in Rehabilitation Psychiatry, North Devon District Hospital, Barnstaple, * *Brenda Moore Consultant in General Adult Psychiatry and Substance Misuse, Department of Psychiatry, Kingshill House, Kingshill Road, Swindon, Wiltshire SN1 4LG, Colin Coles Education Advisor, Wessex and South West Postgraduate Medical and Dental Deaneries 